J䟢ALL JOALL (JOURNAL OF APPLIEI) LINGUIS'TICS ANI) LITIRA'TURE)

Vol. 7 No. 1, February 2022

ISSN (print): 2502-7816; ISSN (online): 2503-524X

Available online at https:/ / ejournal.unib.ac.id/index.php/joall/article/view/14247

http://doi.org/10.33369/joall.v7i1.14247

\title{
The implementation of TPS (think pair share) cooperative learning model aided by Google hangouts in literary expression course
}

\author{
${ }^{1}$ Fina Hiasa ${ }^{D}$, 2 Supadi, ${ }^{3}$ Nafri Yanti \\ 1,2Indonesian Education Study Program, Faculty of Teacher Training and \\ Education, University of Bengkulu, INDONESIA \\ 1,2Jalan W.R. Supratman, Kandang Limun, Bengkulu 38371, Indonesia.
}

3Indonesian Education Study Program, Universitas Pendidikan Indonesia, INDONESIA

${ }^{3}$ Jalan Dr. Setiabudhi No.229, Cidadap, Isola, Sukasari, Isola, Kec. Sukasari, Bandung City

\begin{tabular}{|c|c|}
\hline ARTICLE INFO & ABSTRACT \\
\hline $\begin{array}{l}\text { Article history: } \\
\text { Received: Jan 22, } 2021 \\
\text { Revised: Nov 03, } 2021 \\
\text { Accepted: Nov 11, } 2021\end{array}$ & \multirow{5}{*}{$\begin{array}{l}\text { This study aims to determine how the application of the TPS (Think- } \\
\text { Pair-Share) type of cooperative learning model assisted by Google } \\
\text { Hangout can improve the quality of learning in seventh semester } \\
\text { students of the Indonesian Language Education Study Program, FKIP } \\
\text { UNIB, in the Literary Expression course. The data analysis technique } \\
\text { used in this study was a descriptive method that produced an } \\
\text { overview of the extent to which the quality of learning has improved } \\
\text { by using the TPS (Think-Pair-Share) type of cooperative learning } \\
\text { model assisted by Google Hangouts for students who were the } \\
\text { research samples. This classroom action research was carried out in } \\
\text { two cycles, and each cycle used the main digital learning room, } \\
\text { namely the Google Hangout application. Data collection techniques } \\
\text { were carried out through non-test techniques at the beginning and } \\
\text { end of cycles I and II using questionnaires and observation sheets. In } \\
\text { the first cycle, the results obtained had not reached the expected } \\
\text { target. The target required was reached in the second cycle. The } \\
\text { learning outcomes of the second cycle of students obtained an A score } \\
\text { of } 13 \text { people ( } 36 \% \text { ), a B value of } 18 \text { people ( } 50 \% \text { ), a } C \text { value of } 5 \text { people } \\
\text { (14\%), and a D value of } 0 \text { people ( } 0 \% \text { ). These results indicate that the } \\
\text { target achievement of } 30 \% \text { had been successfully achieved by } \\
\text { applying the TPS learning model assisted by the Google Hangouts. }\end{array}$} \\
\hline $\begin{array}{l}\text { Keywords: } \\
\text { Google Hangout } \\
\text { Literary Expression } \\
\text { TPS (Think-Pair-Share) }\end{array}$ & \\
\hline & \\
\hline $\begin{array}{l}\text { Funding information: } \\
\text { None }\end{array}$ & \\
\hline $\begin{array}{l}\text { Correspondence: } \\
\text { Fina Hiasa, Indonesian } \\
\text { Education Study Program, } \\
\text { Faculty of Teacher Training } \\
\text { and Education, University of } \\
\text { Bengkulu, INDONESIA. } \\
\text { finahiasa@unib.ac.id }\end{array}$ & \\
\hline (c) (†) (? & i \& Nafri Yanti \\
\hline \multicolumn{2}{|c|}{$\begin{array}{l}\text { How to cite (APA Style): } \\
\text { Hiasa, F., Supadi, \& Yanti, N. (2022). The implementation of TPS (think-pair-share) cooperative } \\
\text { model aided by Google hangouts in literary expression course. JOALL (Journal of Applied Linguistics } \\
\text { and Literature), 7(1), 34-50. https:// doi.org/10.33369/joall.v7i1.14247 }\end{array}$} \\
\hline
\end{tabular}


The Covid 19 pandemic, which is still threatening to an undetermined time limit, is a worry for many parties, including in the field of education. The impact is that all face-to-face educational activities are eliminated. Lecturers, teachers, students, and students, including Bengkulu University institutions, are asked to replace face-to-face learning with online learning. Online learning activities where students learn from home will be further extended to an undetermined time limit. Of course, a learning method is needed to deal with learning in the current pandemic era so that students remain active even though learning activities are carried out from home.

One of the subjects affected by this pandemic is the literary expression course. In this course, students practice a lot to achieve learning objectives, namely to be able to express their literary potential. However, due to the Covid 19 pandemic, literary expression activities could not be carried out, which should have been much practice. In addition, student learning outcomes during online learning showed a decrease compared to learning outcomes in the previous semester. Where in the previous semester lecture activities were carried out in classrooms. Learning outcomes that have decreased are also supported by the results of data analysis on questionnaires that researchers have distributed via google form to students.

The purpose of distributing the questionnaire is to find out the interest and motivation of students towards online learning. The distributed questionnaire has first calculated its content validity, which is 0.83 , which means that the non-test instrument in the form of a questionnaire compiled by the researcher is suitable to be used as a research data collection tool. This questionnaire consists of 5 questions related to student interest and motivation in learning activities. The average final score obtained is 3 , which means that students' requests and motivation in the literary expression course fall into the sufficient category.

Based on the decrease in learning outcomes and descriptions of student motivation and interest in learning obtained from the distribution of questionnaires, a learning model is needed that can support learning activities in literary expression courses in the era of online learning. (Suprijono, 2011) states that the selection of appropriate learning models and learning media is expected to create a conducive classroom atmosphere, students are active in learning, students can understand the material presented by the teacher so that learning objectives can be achieved.

Slavin \& Isjoni said, "In cooperative learning methods, students work together in four member teams to master material initially presented by the teacher" (Isjoni, 2011; Slavin \& Solihatin, 2011). In other words, the cooperative learning model can help students express themselves more in exploring science in small groups so as to optimize student participation. 
The implementation of TPS (think-pair-share) cooperative learning model aided by...

Basically, cooperative implies an attitude or behavior together in working or helping among others in an orderly structure of cooperation in groups, consisting of two or more people where the success of work is strongly influenced by the involvement of each member of the group itself (Solihatin \& Suharjo, 2011). One of the cooperative learning models is the Think Pair Share (TPS) type. This learning model affects the interaction patterns of students. TPS itself was first developed by Frank Lyman and his colleagues at the University of Maryand.

Agus Suprijono (2010) in an article written by Hasibuan (2016), states that as the name suggests "thinking," this learning begins with the teacher asking questions or issues related to the lesson for students to think about. The teacher gives them the opportunity to think about the answer. Furthermore, "pairing," at this stage, the teacher asks students to pair up and give the pairs the opportunity to discuss. It is hoped that this discussion can deepen the meaning of the answers student has thought through the intersubjective way with his/her partner. The results of the intersubjective discussion in each pair are discussed with the pairs of the whole class. This stage is known as "sharing" (Teeuw, 1984)

Buchari Alma et al. (2009) in an article written by Armadi (1990) states that Think-Pair-Share is a simple technique that has the advantage of being able to optimize students' participation in expressing opinions and increasing knowledge. Usually, the Think-Pair-Share learning model is applied to conventional classrooms, namely by face-to-face directly. However, with the Covid 19 pandemic and the possibility of extension of social distancing, people are not allowed to be in a crowd, including the crowd of students in the classroom. Thus, the TPS learning model must be accompanied by learning media that allows teaching and learning activities from home(Sayuti, 1994; Surtati, 2017).

Learning media is a tool that functions and can be used to convey learning messages (Musfiqon, 2012). With the development of technology, the world of education is required to change the paradigm of classroom learning. Coupled with the situation and conditions in the world that are currently worsening due to the Covid 19 pandemic, the TPS learning model must be accompanied by technology-based learning media. To accompany the TPS (Think Pair Share) cooperative learning model, the researchers used the Hangout application media as support in learning activities in literary expression subjects. It is hoped that by using the hangout application, students will better understand the material and practice expressing the potential of student literature even though learning activities are carried out from their respective homes. Hangouts are one of the Google Apps that can be used as a formal forum for the online learning process. The reason for choosing Hangouts is because this application is considered relatively easy to 
use and maximally supports the appearance of students in expressing their literary potential.

The Google Hangouts application itself can join hands with a recording application that can be connected to YouTube. Thus, during the video call process, students who are not currently practicing can still see their friends live through the shared YouTube link. Using this application tends to be easy. Lecturers only need to invite students by sending a hangout link via WhatsApp. After the student clicks on the link, they will automatically enter the google hangout chat room. Hangout capacity is not like a zoom that can accommodate up to hundreds. However, the effectiveness, closeness, and convenience offered by Google Hangouts is a solution to overcoming literary expression learning from home. The online learning system in the pandemic era has minimized interactions, resulting in minimal student participation. With the implementation of learning in small groups, even though this is also done online, the passion and motivation of students to learn can be awakened. The hope is that when students are motivated in learning, learning outcomes will also increase.

The latest research that is relevant to the research that the researcher is doing is the research by (Lutfiyatun et al., 2012; Novita, 2014) with the title Application of Think Pair Share (TPS) Learning Model in Chemistry Learning to Improve Argumentation Skills and Learning Motivation of High School Students. The results showed that the application of the Think Pair Share learning model could improve students' argumentation skills and student motivation. In addition, relevant research on the use of google hangouts was carried out by (Purwaningsih, 2019) with the title Application of Blended Learning Through Online Learning Initiation Using Websites and Google Hangouts by Involving Industry Practitioners as an Effort to Improve the Quality of Learning in the Business Environment Classroom. The results of the research published in the journal Reflections on Innovative Learning (RPI) are the formation of 29 new mini start-ups in accordance with the interests of the study group, a class website and an increase in student insight regarding the development of the current industrial world, especially start-up. Furthermore, there is a study conducted by (Fara, 2013; Joyce et al., 2009) entitled Improving Students' Speaking Ability Through the Use of Think-PairShare Method in Class VII-A SMP Al-Ittihad Putri Camplong-Sampang. The results showed that the students' speaking ability had increased, namely the average result of the students in the first cycle of 62.62 and increased in the second cycle, the average value being 75.83 (Trianto, 2009).

The difference between the research that researchers would do and the previous research conducted by (Lutfiyatun et al., 2012) and (Fara, 2013) is that this study only used Think Pair Share (TPS) without google hangout and (Purwaningsih, 2019) only used google hangout. The researchers in this study 
The implementation of TPS (think-pair-share) cooperative learning model aided by...

used a combination of the Think - Pair - Share (TPS) model assisted by google hangout. In addition, the subjects that were used as research subjects were literary expression courses, different from those of previous researchers. The limited research on the TPS model with the help of the google hangout application in the literary expression course is also the reason researchers wanted to do this research. The use of the Google Hangout application allows the effectiveness of learning in the Literary Expression course amid the Covid19 pandemic (Library Of Congress, 2020).

\section{METHOD}

\section{Population and research samples}

This is a Classroom Action Research which was conducted in two cycles. Each cycle consists of four stages: planning, acting, observing, and reflecting, where each cycle used a digital learning space. The research subjects were researchers who worked as lecturers in the Literary Expression course and 36 students who took the subject. The population of this study was all students of the Indonesian Language Education Study Program, FKIP University of Bengkulu. The sample in this study was students of semester VII class B taking the Literary Expression course.

\section{Instruments}

A research instrument is a tool used to collect research data. The instrument used was the observation sheet of the students' appearance of poetry and prose literary expressions.

\section{Data analysis procedures}

This study's data analysis techniques were descriptive statistics, calculating frequency, and percentages presented with tables and graphs. Categories in the data were adjusted according to existing percentages. Following is the formula that was used in the data processing.

$$
\begin{array}{ll}
X=\frac{€ X}{€ X m a k s} & x 100 \% \\
\text { Notes: } & =\text { the value sought in percent } \\
X & =\text { Total student grades } \\
€ X \quad & =\text { Total score } \\
€ X \text { maks } &
\end{array}
$$

Table 1: Scoring System (Nurgiyantoro, 2001, p. 363)

\begin{tabular}{ll}
\hline \multicolumn{1}{c}{ Percentage } & \multicolumn{1}{c}{ Category } \\
\hline $80 \%-100 \%$ & Very good \\
$70 \%-79 \%$ & Good
\end{tabular}




\begin{tabular}{ll}
\hline \multicolumn{1}{c}{ Percentage } & \multicolumn{1}{c}{ Category } \\
\hline $60 \%-69 \%$ & Fair \\
$45 \%-59 \%$ & Bad \\
$0 \%-44 \%$ & Very bad \\
\hline
\end{tabular}

\section{FINDINGS}

Based on research conducted at the end of July to December on 36 students by implementing the TPS type cooperative learning model (Think-Pair-Share) assisted by Google Hangout at Bengkulu University, the following final results were obtained.

Table 2: of Students' Score in Cycle 1 and 2

\begin{tabular}{cccccccc}
\hline $\begin{array}{c}\text { Score } \\
\text { Interval }\end{array}$ & Grade & Description & $\begin{array}{c}\text { The Acquisition } \\
\text { of Score in Cycle } \\
\text { 1 }\end{array}$ & $\begin{array}{c}\text { The } \\
\text { Acquisition of } \\
\text { Score in Cycle 2 }\end{array}$ & $\begin{array}{c}\text { Achievement } \\
\text { Target }\end{array}$ \\
\hline $85-100$ & A & Very good & 10 & $28 \%$ & 13 & $36 \%$ & $30 \%$ \\
$65-79$ & B & Good & 18 & $50 \%$ & 18 & $50 \%$ & $50 \%$ \\
$55-64$ & C & Fair & 8 & $22 \%$ & 5 & $14 \%$ & $20 \%$ \\
$0-54$ & D & Bad & 0 & $0 \%$ & 0 & $0 \%$ & $0 \%$ \\
& Total & & 36 & $100 \%$ & 36 & $100 \%$ & $100 \%$ \\
\hline
\end{tabular}

The table above shows the learning outcomes obtained by students in cycle I before implementing the cooperative learning model type TPS (ThinkPair-Share) assisted by google hangout and in cycle II after the cooperative learning model type TPS (Think-Pair-Share) assisted by google hangout was implemented. From the table above, it can be seen that the increase in learning outcomes occurred in cycle II, with the achievement of learning completeness for the very good category reaching $36 \%$ or as many as 13 students. The learning outcomes in the second cycle showed an increase compared to the first cycle, where in the first cycle, the learning mastery achievement of $30 \%$ had not been fulfilled. Next, in the following explanation, we describe the details of the learning process that occurs in cycles I and II. This research was class action research (Classroom Action Research) which was conducted in two cycles. Each cycle consisted of four stages: planning, acting, observing, and reflecting, where each cycle used a digital learning space.

\section{Cycle 1}

After preparing learning materials, observation instruments, and questionnaires were ready, the learning process was carried out in cycle I. The purpose of learning carried out in cycle I is that students can express their literary interest in prose literary works by writing short stories with certain themes. In the first cycle, learning was carried out by lecturers delivering 
The implementation of TPS (think-pair-share) cooperative learning model aided by...

material to students using digital spaces such as zoom and e-learning UNIB. In this case, the learning pattern was only in the same direction where more lecturers were active in providing knowledge about literary expression. The learning results from the implementation of learning in cycle I show that the achievement targets in the Literary Expression course have not been fulfilled with the following details. A total of 10 students (28\%) got an A, 18 students $(50 \%)$ got a $\mathrm{B}$ grade, 8 students $(22 \%)$ got a C, and 0 students $(0 \%)$ got a $\mathrm{D}$. cycle I shows that the $30 \%$ achievement indicator in the Literary Expression course has not been achieved.

In addition, the results of filling out the questionnaire by students on the learning responses that had been carried out in cycle I showed a lack of interest and motivation for students in learning that occurred in cycle I. The following is the distribution of student choices regarding the statements listed in the questionnaire, which are summarized in table form.

Table 3: The Results of the Questionnaire in Cycle I

\begin{tabular}{lcccc}
\hline \multicolumn{1}{c}{ Statement Items } & \multicolumn{4}{c}{ EVALUATION CRITERIA } \\
\cline { 2 - 5 } & ST/SB & T/B & CT/CB & KB/KT \\
\hline I understand the structure of the short story & 3 & 22 & 6 & 5 \\
$\begin{array}{l}\text { I understand the application of short story } \\
\text { structure in short story writing }\end{array}$ & 3 & 15 & 15 & 3 \\
$\begin{array}{l}\text { I will be able to express short stories well } \\
\begin{array}{l}\text { I can describe what kind of short story I will } \\
\text { make }\end{array}\end{array}$ & 1 & 12 & 10 & 13 \\
$\begin{array}{l}\text { I know how to express literature in prose (short } \\
\text { story) }\end{array}$ & 8 & 8 & 20 & 5 \\
\hline
\end{tabular}

$\mathrm{ST} / \mathrm{SB}=$ really know/really can $\mathrm{CT} / \mathrm{CB}=$ quite know/quite able to
$\mathrm{T} / \mathrm{B}=$ know/can

$\mathrm{KB} / \mathrm{KT}=$ do not know/less able to

Based on the table above, it appears that the first statement shows student responses as many as 22 students (61\%) answered know/can. The second statement shows a balanced result in which the number of ST / SB-T / B and CT / CB - KB / KT is 18 students (50\%). Furthermore, in the third statement, most students chose not knowing / not being able to do so, namely as many as 13 students (36\%). Finally, the fourth and fifth statements obtained the same number; namely, 20 students (55.5\%) answered CT / CB. In general, it can be concluded that students did not really understand the material and how to apply it. It can be seen from the answer choices of students who chose to know enough or enough to be the statement with the largest total gain. 


\section{Cycle 2}

The planning of the material and the implementation of learning in the literary expression course that occurred in cycle II was associated with the application of the TPS (Think-Pair-Share) Assisted Learning Model with Google Hangout. The implementation of the TPS learning steps (Prita \& Krismiyati, 2015), which is made in tabular form, is as follows.

\section{Table 4: Stages and Implementation of TPS}

\section{STEPS}

\section{Think}

This learning began with the teacher asking questions or issues related to the lesson for students to think about. The teacher gave them a chance to think about the answer.

Pair

At this stage, the teacher asked the students in pairs to discuss. It is hoped that this discussion could deepen the meaning of the answers that had been thought through intersubjectively with their partners.

\section{Share}

The results of intersubjective discussions in each pair were discussed with the whole class pair.

\section{IMPLEMENTATION}

At this stage, students were asked to remember the sentences in the most memorable poem for each of them. After that, students were randomly asked to explain why the poem's words were very memorable for students. This learning activity used the Google Hangouts application.

Furthermore, the lecturer gave the task to the students to write a poem with a predetermined theme. The theme choices were as follows, 1) humans and covid 19,2) garbage and humans, 3) forests and humans, and 4) land and humans. Before writing individual poems, students were paired to discuss the themes they had obtained ( 2 students had one theme and were required to share knowledge about the themes that had been obtained). The discussion was conducted using the Google Hangouts application, which had advantages such as video calls on WhatsApp, so the discussion felt more intense and relaxed. In addition, discussions were also carried out by utilizing the message feature of Google Hangouts.

After the poetry script is ready, the students read the poem and record it in the form of a video to be uploaded to the class YouTube channel. Each pair would be asked to share their views on the theme raised in the poem that had been made in a digital classroom using the Google Hangouts application.

The implementation of learning using TPS (Think-Pair-Share) assisted by google hangout in cycle II obtained results that exceeded the predetermined targets. Students had the opportunity to develop their knowledge of specific themes with their partners in pairing and sharing activities using the help of the google hangout application. It makes it easier for students to understand the assignment given because it was discussed 
The implementation of TPS (think-pair-share) cooperative learning model aided by...

intensively and closely. Also, there is comfort when the discussion took place because each group only consisted of 2 people with the same theme. The result is that students' literary expression in literary expression material in the form of poetry works results in line with expectations, even exceeds the target achievement (Novita, 2014).

Thirty-six students read the poems they made with a particular theme; the results were based on the observation sheet with the following details. As many as 13 students (36\%) got an A, 18 students $(50 \%)$ got a B grade, 5 students $(14 \%)$ got a $C$, and 0 students $(0 \%)$ got a D. Cycle II shows that the achievement indicator in the Literary Expression course is $30 \%$ by implementing the TPS (Think-Pair-Share) cooperative learning model assisted by google hangout has been achieved and has even succeeded in exceeding the target.

In addition, the results of filling out a questionnaire by students regarding the learning response that had been carried out in cycle II by applying the TPS (Think-Pair-Share) cooperative learning model assisted by google hangout show that on average, students became more motivated in expressing their literature. The following is the distribution of student choices for the statements listed in the questionnaire, summarized in tabular form.

\section{Table 5: The Results of the Questionnaire in Cycle II}

\begin{tabular}{lcccc}
\hline \multirow{2}{*}{ STATEMENT ITEMS } & \multicolumn{4}{c}{ EVALUATION CRITERIA } \\
\cline { 2 - 5 } & ST/SB & T/B & CT/CB & KB/KT \\
\hline $\begin{array}{l}\text { I feel excited to express my interest in specific } \\
\text { categories of literary works }\end{array}$ & 26 & 6 & 4 & 0 \\
$\begin{array}{l}\text { I feel happy when I make literary expression } \\
\text { assignments }\end{array}$ & 25 & 5 & 6 & 0 \\
$\begin{array}{l}\text { I find it easier with the help of the google } \\
\text { hangout application in learning literary } \\
\text { expression }\end{array}$ & 30 & 6 & 0 & 0 \\
$\begin{array}{l}\text { I feel able to express my interest in literature. } \\
\begin{array}{l}\text { I find it easier to apply think-pair-share to the } \\
\text { literary expression course }\end{array}\end{array}$ & 25 & 5 & 6 & 0 \\
\hline
\end{tabular}

$\mathrm{ST} / \mathrm{SB}=$ really know/really can

$\mathrm{CT} / \mathrm{CB}=$ quite know/quite able to
$\mathrm{T} / \mathrm{B}=$ know/can

$\mathrm{KB} / \mathrm{KT}=$ do not know/less able to

Based on the table above, it appears that the first statement shows students' responses as many as 26 students $(72 \%)$ answered yes. The second statement shows almost the same results; namely, 25 students $(69 \%)$ agreed to the second statement. Furthermore, in the third statement, students chose yes, the most, namely 30 students (83\%). Finally, for the fourth and fifth statements, respectively, 25 students $(69 \%)$ agreed to the fourth statement, and as many as 30 students (83\%) approved the fifth statement. 
Students responded to the questionnaire given after learning in cycle II applied the TPS (Think-Pair-Share) cooperative learning model assisted by google hangout. On average, students became more motivated in expressing their literature. It can be seen from the responses of students who, on average, agreed to the statements in the questionnaire given in cycle II. It means that learning was more fun, and the material obtained was easier to apply to express students' interest in literature than in learning that occurred in cycle I.

\section{DISCUSSION}

The implementation of TPS (Think-Pair-Share) assisted with Google Hangout in cycle II shows satisfactory results because it reached and even exceeded the predetermined percentage of success indicators. Students became more enthusiastic in implementing TPS (Think-Pair-Share) because there is a process where students are paired with one of their friends. Then they will have a casual discussion about a particular topic and share their knowledge about that topic. This familiar but academic pattern makes it easier for students to understand the material and carry out the assignments given by the lecturer. The result is the literary expression carried out by students, which in this case occurred in cycle II, namely with the task of writing poetry and reading it and recording it in video form, showing encouraging results, where many students demonstrated and also developed poetry writing skills and poetry reading skills.

In addition, the digital space used is google hangout, where the application can be said to be very friendly to its users. This convenience is also very helpful for in-depth discussions carried out by small groups of only two people, further supporting students' understanding of the topics to be raised. The problem that occurs when learning distance is the internet connection. There are some students who remain in their hometowns because the university is not open as usual, while the Covid 19 pandemic is still spreading, and the signals in their hometowns are not good. However, these obstacles could be overcome properly in cycle II. This can be seen from the learning outcomes of students who have succeeded in achieving the target of learning outcomes.

The application of the TPS (Think-Pair-Share) cooperative learning model with the help of google hangout for the Literary Expression course for PBI UNIB semester VII students of class B of the 2020/2021 academic year can improve student learning outcomes. The achievement of the percentage of completeness target occurred after the application of the TPS (Think-PairShare) type of cooperative learning model assisted by google hangout in cycle II. Apart from the main Google Hangouts application, the research team also used other applications such as e-learning UNIB, zoom, and YouTube, which 
The implementation of TPS (think-pair-share) cooperative learning model aided by...

helped the research run smoothly. The results in the first cycle show that $30 \%$ of the indicators of success in implementing TPS were not achieved. Of the 36 students who expressed literature by writing short stories, only 10 students $(28 \%)$ got an A. While the rest were 18 students $(50 \%)$ who got a B grade. Value of $\mathrm{C}$ as many as 8 people (22\%) and value of $\mathrm{D}$ as many as 0 people $(0 \%)$. The learning outcomes obtained by students in the first cycle can be said to be quite good because they had obtained a B grade of $50 \%$, but the target achievement was the highest learning outcomes, at least reaching $30 \%$. Based on student learning outcomes in cycle I that had not met the target, the highest achievement was at least, so research activities needed to be continued to cycle II.

The learning results in the second cycle, of 36 students who read the poems they made with a certain theme, the results of the assessment were based on the observation sheet with the assessment categories, namely 1) tempo (25), 2) appreciation (15), 3) tone (15), 4) facial expression (15), and 5) interpretation (30), the following data are obtained. As many as 13 students (36\%) got an A, 18 students (50\%) got a B grade, 5 students $(14 \%)$ got a $C$, and 0 students $(0 \%)$ got a D. The Cycle II shows that the achievement indicator in the Literary Expression course is $30 \%$ by implementing the TPS (Think-PairShare) cooperative learning model assisted by google hangout had been achieved and had even succeeded in exceeding the target.

\section{CONCLUSION}

From the results of the research that has been done, it can be concluded as follows; 1) The application of the TPS (Think-Pair-Share) cooperative learning model assisted by google hangout for the Literary Expression course semester VII students of class B can improve student learning outcomes. Completeness of learning can be obtained in cycle II of the two planned cycles. 2) This increase in learning outcomes shows that the cooperative learning model type TPS (Think-Pair-Share) assisted by google hangout is a solution that can be applied in dealing with online learning.

This is because the learning model used allows students to carry out discussions as if with peers like conventional learning before the Covid 19 pandemic. The limited study group ( 2 people per group) makes the learning and sharing atmosphere more quality. Hopefully, in applying the TPS (ThinkPair-Share) cooperative learning model assisted by google hangout. The lecturer can develop more attractive strategies so that online learning becomes more attractive to students. Also, increased student activity and learning outcomes.

Previous research that only applied the TPS model or only applied the use of google hangouts showed an increase in learning outcomes. The researcher combines the TPS learning model with the Google Hangout 
application as a strategy in online learning activities. As a result, the set achievement targets were successfully exceeded. This indicates that the combination of technology, namely the Google Hangout application and also the TPS learning model is a solution in increasing student motivation in learning activities. In addition, the increase in student motivation to learn also has implications for improving learning outcomes. In addition, lecturers can apply the TPS type cooperative learning model (Think-Pair-Share) assisted by Google Hangouts in other courses

\section{REFERENCES}

Armadi, M. (1990). Strategi Belajar Mengajar Keterampilan Berbahasa dan Apresiasi Sastra. YA3.

Fara, S. (2013). Peningkatan Kemampuan Berbicara Siswa Melalui Penggunaan Metode Tps (Think-Pair-Share) Di Kelas Vii-A Smp Al-Ittihad Putri Camplong-Sampang. Universitas Muhammadiyah Malang.

Hasibuan, A. Y. (2016). Pengaruh Model Pembelajaran Think-Pair-Share

(TPS) Terhadap Kemampuan Memahami Unsur Intrinsik Cerpen Pada Siswa Kelas X SMA Negeri 8 Padang Sidimpuan. Jurnal Bahasa Dan Sastra, Vol.1 No.1.

Isjoni. (2011). Cooperative Learning Efektifitas Pembelajaran Kelompok. Alfabeta. Joyce, Weil, M., \& E Calhoun. (2009). Models of Teaching : Model-model Pengajaran. Pustaka Belajar.

Library Of Congress. (2020). Indonesia: Spread of COVID-19 Declared a

National Disaster. In Library of Congress, Washington, D.C. 20540 USA. https://www.loc.gov/item/global-legal-monitor/2020-0417/indonesia-spread-of-covid-19-declared-a-national-disaster/ Lutfiyatun, Widodo, J., \& Martono. (2012). Implementasi Metode Think Pair Share (TPS) Berbantuan Media Power Point Pada Pembelajaran Kewirausahaan Pokok Bahasan Proposal Usaha Untuk Meningkatkan Keaktifan Dan Hasil Belajar Siswa Kelas Xi SMK Negeri 1 Dukuhturi Kabupaten Tegal. Economic Education Analysis Journal, Vol.1 No.2. Musfiqon. (2012). Pengembangan Media dan Sumber Pembelajaran. Prestasi Pustaka.

Novita, R. (2014). Efektivitas Model Pembelajaran Kooperatif Tipe Think Pair Share (TPS) pada Materi Trigonometri di Kelas XI IA1 SMA Negeri

8 Banda Aceh. Visipena, Vo.5 No.1, 128-135.

Nurgiyantoro, B. (2001). Penilaian dalam Pengajaran Bahasa dan Sastra. BPFE.

Prita, O. N., \& Krismiyati. (2015). Pengaruh Metode Pembelajaran

Cooperative Tipe TPS ( Think-Pair-Share ) Berbantuan Video Tutorial Dalam Mata Pelajaran Simulasi Digital (Studi Kasus Smk N 2 Salatiga )

Kata Kunci : Keaktifan , Cooperative tipe TPS ( Think-Pair-Share ), Media Pembelajaran. In Core.ac.uk (p. 2). 
The implementation of TPS (think-pair-share) cooperative learning model aided by...

https://core.ac.uk/download/pdf/288110821.pdf

Purwaningsih, T. (2019). Penerapan Blended Learning Melalui Inisiasi

Pembelajaran Online Menggunakan Website dan Google Hangout dengan Melibatkan Praktisi Industri Sebagai Upaya Peningkatan Kualitas Pembelajaran di Kelas Business Environment. Refleksi Pembelajaran Inovatif, 1(2), 123-135.

https:/ / doi.org/10.20885/rpi.vol1.iss2.art3

Sayuti, A. S. (1994). Apresiasi Prosa Fiksi. Dekdikbud.

Slavin, \& Solihatin. (2011). Psikologi Pendidikan Teori dan Praktek Jilid 2. Indeks.

Solihatin, \& Suharjo. (2011). Cooperative Learning Analisis Model Pembelajaran IPS. Bumi Aksara.

Suprijono. (2011). Cooperative learning: Teori dan aplikasi Paikem. Pustaka Belajar.

Surtati, T. (2017). Kiat Sukses Meraih Hibah Penelitian Pengembangan.

Deepublish.

Teeuw, A. (1984). Sastra dan Ilmu Sastra, Pengantar Teori Sastra. Pustaka Jaya.

Trianto. (2009). Mendesain Model Pembelajaran Inovatif-Progresif. Kencana

Prenada Media Group.

\section{THE AUTHOR}

Fina Hiasa, Supadi, and Nafri Yanti are lecturers at the Indonesian Education Study Program, Faculty of Teacher Training and Education, University of Bengkulu, INDONESIA who are actively teaching subjects in the fields of literature, language, and education at Bengkulu University. 